\title{
Annual report on the implementation of Council Regulation (EC) No 812/2004 - 2016
}

A.S. Couperus

CVO Report 18.008

Mei 2018

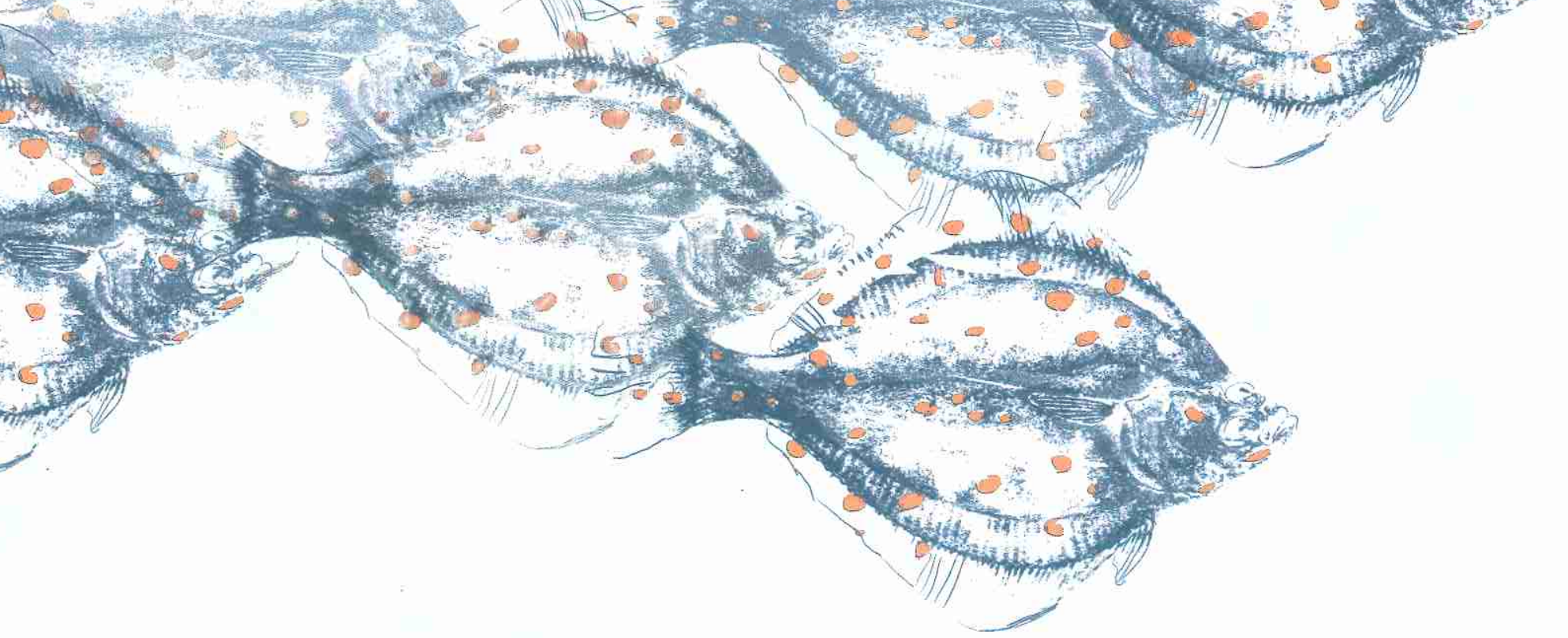




\section{Stichting Wageningen Research Centre for Fisheries Research (CVO)}

\section{Annual report on the implementation of Council Regulation (EC) No 812/2004 - 2016}

A.S. Couperus

CVO report: 18.008

Commissioned by:

Ministerie van EZ, Directie ELVV

Postbus 20401

2500 EK Den Haag

T.a.v. Ir.I.H. Janssen

Project number:

BAS code:

DOI nummer:
4311213026, 4311213027

WOT-05-001-004-Monitoring bijvangsten

https://doi.org/10.18174/450585 
Stichting Wageningen Research

Centre for Fisheries Research (CVO)

P.O. Box 68

1970 AB IJmuiden

Phone. +31 (0)317-487418

Fax. $+31(0) 317-487326$

Visitor address:

Haringkade 1

1976 CP IJmuiden

\section{(C) 2017 CVO}

De Stichting Wageningen ResearchCentre for Fisheries Research is registered in the Chamber of commerce in Gelderland nr. 09098104, VAT nr. NL 8089.32.184.B01

CVO rapport UK V07
This report was prepared at the request of the client above and is his property. No part of this report may appear and / or published, photocopied or otherwise used without the written consent of the client. 


\section{Annual report on the implementation of Council Regulation (EC) No 812/20041 - 2016}

\section{Member State: Netherlands}

\section{Reference Period: 2016}

Date: 21 February 2018

\section{Author: A.S. Couperus}

1 Council Regulation (EC) No 812/2004 of 26.4.2004 laying down measures concerning incidental catches of cetaceans in fisheries and amending Regulation (EC) No 88/98.

Article 6 of the Regulation,

1. Each year, Member States shall send the Commission, by 1 June, a comprehensive annual report on the implementation of Articles 2, 3, 4 and 5 during the previous year. The first report shall cover both the remaining part of the year following the entry into force of this Regulation and the entire year that follows.

2. On the basis of the observers' reports provided according to Article 5(3) and all other appropriate data, including those on fishing effort collected in application of Council Regulation (EC) No 1543/2000 of 29 June 2000 establishing a Community framework for the collection and management of the data needed to conduct the common fisheries policy, the annual report shall include estimates of the overall incidental catches of cetaceans in each of the fisheries concerned. This report shall include an assessment of the conclusions of the observers' reports and any other appropriate information, including any research conducted within the Member States to reduce the incidental capture of cetaceans in fisheries. When reporting on the results of scientific studies or pilot projects as provided for in Articles 2(4) and 4(2), Member States shall ensure that sufficiently high quality standards are reached in their design and implementation and shall provide detailed information concerning those Standards to the Commission. 


\section{Table of Contents}

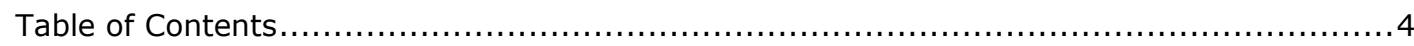

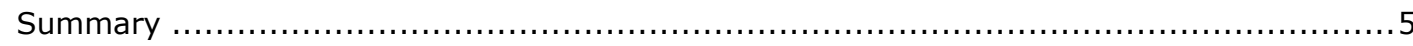

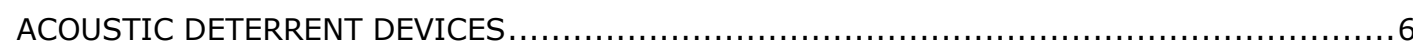

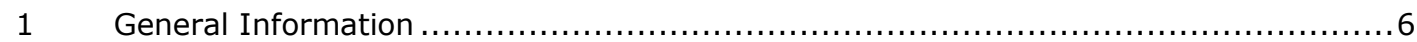

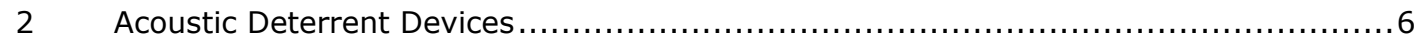

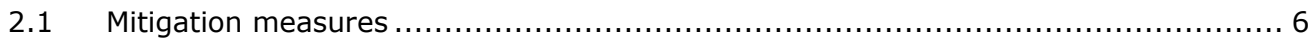

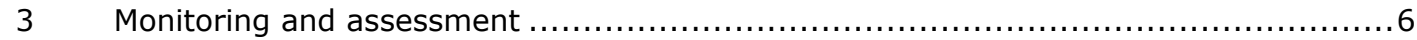

3.1 Monitoring and assessment of the effects of pinger use $\ldots \ldots \ldots \ldots \ldots \ldots \ldots \ldots \ldots \ldots \ldots \ldots \ldots \ldots \ldots \ldots \ldots \ldots$

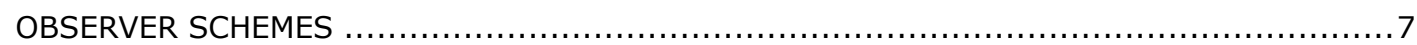

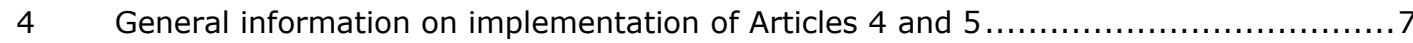

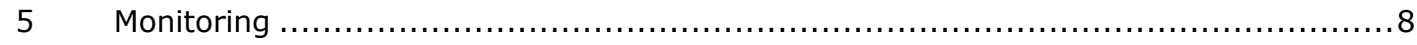

5.1 Description of fishing effort and observer effort in towed gear ...................... 8

5.2 Description of fishing effort and observer effort in static gear $\ldots \ldots \ldots \ldots \ldots \ldots \ldots \ldots \ldots \ldots$

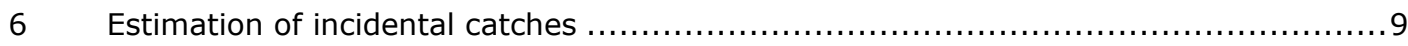

6.1 Incidental catch rates by fleet segment and target species ........................ 9

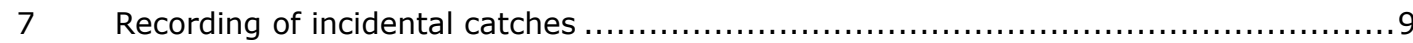

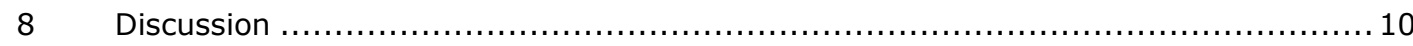

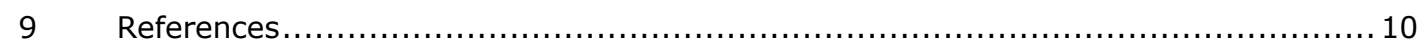

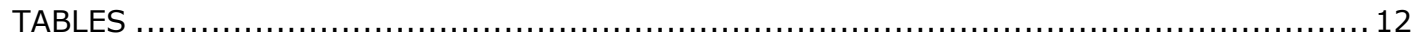

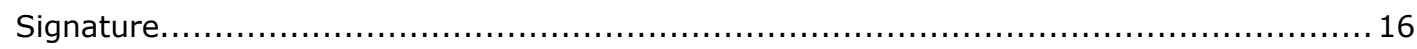




\section{Summary}

This report contains the results of the on-going monitoring programme on the incidental bycatch of cetaceans in Dutch pelagic fisheries in 2016. EU Council Regulation 812/2004 requires observer coverage in ICES areas VI, VII and VIII in the period 1 December - 31 March (fleet segment NLD003) and outside this area in all areas year round (fleet segment NLD004). In the Dutch situation the monitoring is integrated with the collection of catch data under the EC Data Collection Regulation 199/2008 and Decision 93/2010.

In 2016, during 7 fishing trips, 32 days and 81 hauls were observed in fleet segment NLD003, and 85 days and 192 hauls were observed in fleet segment NLD004. With a total number of fleet days of 368 in fleet segment NLD003 and 770 in fleet segment NLD004, the coverage was $8.7 \%$ and $11.0 \%$ respectively. Thus the target of the Pilot Monitoring Scheme (PMS) of 10\% for NLD003 and 5\% for NLD004 has not been fulfilled. Five of twelve trips monitored by the Netherlands, were on board two German ( 3 trips) and one French ( 2 trips) flagged trawlers. The observer effort consisted of 46 days (127 hauls) on board the German trawlers and 23 days ( 57 hauls) on the French trawler, covering approximately $59 \%$ of the total Dutch monitoring effort. The data collected during these trips will be made available to the ICES database on incidental bycatch.

The observed bycatch rate of 0.00 dolphins per day in the pelagic fishery is in line with the findings in 2006 - 2015 when the bycatch rate was 0.00-0.01 dolphins per day.

In addition to cetaceans, this report includes information on incidental bycatches of species listed in Table 1D of EU Decision 2016/2051. Three blue fin tuna (Thunnus thynnus) were caught during two incidents by the NLD003 and NLD004 fleet segments in 2016. 


\section{ACOUSTIC DETERRENT DEVICES}

\section{General Information}

EU regulation 812/2004 obliges the use of pingers in set gill net and drift net fleet segments. According to the criteria mentioned in the regulation, the Dutch fishery includes no fleet segments in which pingers are mandatory.

\section{Acoustic Deterrent Devices}

\section{1}

Mitigation measures

The use of pingers is obligatory in ICES sub area IV for vessels larger than $12 \mathrm{~m}$ in the period 1 August till 31 October, using nets that do not exceed $400 \mathrm{~m}$ length (the regulation intents to cover set nets fishery at wrecks, where relatively short net lengths are being used). The vast majority of the Dutch set gillnet fleet fishes in this period for sole with much longer nets.

\section{Monitoring and assessment}

\subsection{Monitoring and assessment of the effects of pinger use}

If some vessels are required to use pingers, this is not registered or known by governmental authorities, nor are the fishermen aware that they should use pingers. Most probably, no acoustic deterrents are in use by Dutch gill net fishers. This would be against the EU Council Regulation 812/2004 . However, most likely the number of vessels larger that $12 \mathrm{~m}$ fishing on wrecks (that is with nets that not exceed $400 \mathrm{~m}$ ) is very low if not zero. 


\section{OBSERVER SCHEMES}

\section{General information on implementation of Articles 4 and 5}

Council Regulation No 812/2004 2 obliges Member States to monitor bycatches of cetaceans in certain fisheries, certain periods of the year and in certain European Waters and to report the results of the monitoring to the European Commission. In the Netherlands, the monitoring is commissioned by the Ministry of Agriculture, Nature and Food Quality to Wageningen Marine Research (WMR). The aim of this study is to assess the incidental bycatch of cetaceans in the Dutch pelagic fisheries.

Under the regulation the following fleet segments in the Netherlands should be monitored:

- $\quad$ Pelagic fishery in the period of 1 December till 31 March in ICES areas VI, VII and VIII; in this report referred to as fleet segment NLD003 for single pelagic vessels.

- $\quad$ Pelagic fishery in European waters during the year excluding the fishery in the period 1 December till 31 March in ICES areas IV, VII and VIII; in this report referred to as fleet segment NLD004 for single pelagic vessels.

The regulation does not require monitoring of fishery with set gill nets in ICES area IVc where (most of) the overall fishery activity from Dutch ports takes place. However, observer effort in set gill net fishery is reported here, because gill nets are known to be relatively sensitive for incidental bycatch of cetaceans and the regulation encourages the execution of pilot studies in other fleet segments.

Under the regulation, a coverage should be reached leading to a CV of the bycatch estimate of $30 \%$ or less. However, in a situation where there are very few bycatch incidents, this CV is not realistic (ICES, 2009). Therefore, the target of the current monitoring programme in the Netherlands is to cover the fleet effort according to the Pilot Monitoring Scheme (PMS), in the Regulation originally set for the first two years. The required pilot coverage is $10 \%$ (effort fishing days) for the period of 1 December till 31 March in ICES area VI, VII and VIII and 5\% in the remainder of the year with exclusion of fleet segment NLD003. In the Dutch situation the monitoring is integrated with the collection of catch data through scientific observers under the EU Data Collection Framework: CD 2010/93 3 and CR 199/2008 ${ }^{4}$. The project under this regulation aims at an overall coverage of approximately $10 \%$ fishing effort (days) in European waters and includes pelagic trawlers under foreign flag, which land the catch in Dutch ports. Data collected under EC. Reg. 812/2004 on board of these vessels are sent to the scientists responsible for the execution of the national monitoring programs in their countries.

Earlier studies on the incidental bycatch of cetaceans have been reported by Couperus $(1995,1997 a)$ covering the period $1992-1996$. The period $2004-2015$ is covered by standard reports on the implementation of EC Regulation 812/2004.

2 Council Regulation (EC) No 812/2004 of 26.4.2004 laying down measures concerning incidental catches of cetaceans in fisheries and amending Regulation (EC) No 88/98

3 Commission Decision 2010/93 of 18 December 2009 adopting a multiannual Community programme for the collection, management and use of data in the fisheries sector for the period 2011-2013 (extended to 2016) 4 COUNCIL REGULATION (EC) No 199/2008 of 25 February 2008 concerning the establishment of a Community framework for the collection, management and use of data in the fisheries sector and support for scientific advice regarding the Common Fisheries Policy 
Monitoring of bycatch of cetaceans is conducted by of the Centre of Fisheries Research (Centrum voor Visserijonderzoek: CVO) on behalf of the Ministry of Agriculture, Nature and Food Quality. CVO hires WMR staff to carry out the observer trips and to prepare the report.

Difficulties: In the observer programme for pelagic freezertrawler fleet the observer effort is spread quasi random over the year. The observer trips are scheduled equally over the year and observers join the first trawler that comes in if accommodation is available. However, the choice of area and target species are often last minute decisions of the owner of the vessel and may even alter during the trip itself.

Therefore, it is impossible to foresee or plan the exact effort in the area that has to be monitored under EC Regulation No 812/2004.

The fact that the sampling program includes the monitoring of vessels that are fishing under foreign flag and land in Dutch ports, adds to the unpredictability of the coverage of the Dutch fleet segments.

\section{$5 \quad$ Monitoring}

\subsection{Description of fishing effort and observer effort in towed gear}

In 2016 the pelagic freezer trawler fleet consisted of 20 freezertrawlers of which 7 fished under Dutch flag. The freezertrawlers fishing from December to March in ICES sub areas VI, VII and VIII are labelled fleet segment NLD003. Fleet segment NLD004 are the same freezertrawlers fishing in area's I-XIV all year round. The single set of pair trawlers did not fish in 2016 (in reports till 2007 the freezertrawlers and the pair trawlers have been treated as one fleet consisting of two fleet segments; from 2008 till 2013 they were treated as a separate fleet).

In 2016 an observer joined 7 trips that can be attributed to segments NLD003-NLD004, corresponding with 117 observer days. According to the national logbook database, the number of days fished by the whole pelagic Dutch flagged fleet (NLD003-NLD004) in 2016 was 1138 days. With 117 observer days the overall coverage of the Dutch pelagic fleet was $10.3 \%$. The number of sampled hauls was 273,81 in NLD003 and 192 in NLD004. The text table provides the effort and coverage by fleet segment:

\begin{tabular}{lcccc}
\hline Fleet segment & Fleet days & Observer days & $\begin{array}{c}\text { Coverage required } \\
\text { according to PMS }\end{array}$ & Coverage achieved \\
\hline Pelagic trawl (NLD003) & 368 & 32 & $10 \%$ & $8.7 \%$ \\
Pelagic trawl (NLD004) & 770 & 85 & $5 \%$ & $11.0 \%$ \\
Trammel nets & 96 & 2 & $0 \%$ & $2.1 \%$ \\
Gill nets & 1970 & 6 & $0 \%$ & $0.3 \%$ \\
Set Nets (unspecified) & 64 &.. &.. &.. \\
\hline
\end{tabular}

Table 2 provides fleet effort and observer coverage by ICES subarea.

Notice that a vessel may have visited several areas on one day which means that a day on which a vessel fished in two areas is counted as two days. Thus the sum of all days at sea is not necessarily the same as the total fishing days at sea. Observer days and fleet days during which no fishing took place are not counted as effort days.

In addition to the 7 trips on board Dutch flagged freezertrawlers, 5 observer trips took place on board foreign flagged freezertrawlers; two trips on board French flagged vessels and 3 trips on board German flagged vessels. On board one French trawler, two trips (23 days), 57 hauls have been monitored, no 
bycatches were observed. On board of two German vessels, three trips (46 days), 127 hauls have been monitored. This is together 184 hauls, during 69 days, consisting of $59 \%$ of the total Dutch observer effort in the pelagic freezertrawler fishery. The data collected during these trips on foreign vessels are made available to the ICES database on incidental bycatch (WGBYC Database). On the foreign vessels no bycatch incidents of cetaceans have been observed.

\subsection{Description of fishing effort and observer effort in static gear}

In 2016 the set gill net fishery was monitored under the DCF (see footnotes paragraph 4 ). The Dutch set gill net fleet consists of 70-100 vessels. Most of them are operated by part time fishermen. Therefore, many vessels do not fish for extended periods during the year. Some do not fish at all. Most of the vessel fish with tangle nets for sole. Part of the fleet (5-10 vessels, depending on the catches and the market) switches in winter to trammel nets, targeting cod, turbot and mixed flatfish (brill, plaice, dab, flounder). A few vessels may fish at wrecks with gill nets for cod or near dams for bass. Since most vessels are very small, trip duration is normally 1 day. Approximately five vessels are larger than $12 \mathrm{~m}$ and may stay at sea overnight.

The Dutch government aims to sample 10 trips per year without pre-stratification to net type. Due to lack of cooperation, only 8 trips were sampled in 2016.

\section{Estimation of incidental catches}

\subsection{Incidental catch rates by fleet segment and target species}

In the Dutch pelagic fishery monitoring programme (fleet segment NLD003 and NLD004) and in the gill net fishery, no incidental bycatch incidents of cetaceans were reported. Incidental bycatch of noncetacean species, including birds, mammals and reptiles and fish protected under Union legislation and international agreements as listed in Table 1D of the new $\mathrm{DCF}^{5}$, consisted of 3 incidents in which 4 blue fin tuna (Thunnus thynnus) were caught, resulting in an estimated bycatch rate of 4 specimens per day in ICES area 27.7.d in fleet segment NLD003 and 15.6 specimens per day in ICES area 27.7.g in fleet segment NLD004 (table 4).

Some incidental bycatch incidents were recorded during the observer trips on board foreign vessels. German vessel: 1 blue fin tuna on 3 March in ICES area 27.8.d in a haul without further catch; 1 blue fin tuna and 2 sunfish (Mola mola) in ICES area 27.8.b in a haul with a small catch of pilchard). These data will be added to the dataset of the involved countries for the calculation of the bycatch rate.

\section{$7 \quad$ Recording of incidental catches}

On board the pelagic freezertrawlers, the observer was present on the bridge during shooting and hauling of each tow. Position and time were recorded at the beginning of each haul. The time was recorded again when hauling started. The rear window of the bridge gives a good view on the rear deck, so that bycatches of cetaceans can be recorded from there. Any incidental bycatch, species and number of specimens must be recorded and if possible length and sex of each specimen.

5 COMMISSION IMPLEMENTING DECISION (EU) 2016/1251 of 12 July 2016 adopting a multiannual Union programme for the collection, management and use of data in the fisheries and aquaculture sectors for the period 2017-2019 (notified under document C(2016) 4329) 
On board gill net vessels, the hauling continues over extended periods of time. Observers take length frequency samples of the fish caught during hauling. Therefore they may miss the bycaught specimens of cetaceans that drop out of the net before the net during the process of hauling. For this reason numbers presented in this report are considered to be minimum numbers. However, given the closeness of the observer to the actual hauling process on board these very small vessels, it is believed that the observed numbers are unlikely to differ from the actual numbers.

\section{Discussion}

With $8.7 \%$ coverage of fleet segment NLD003 the PMS target of $10 \%$ has not been fulfilled. The target of $5 \%$ for the fleet segment NLD004 has been fulfilled (11.0\% coverage). As explained above, the observer effort is combined with the DCF sampling following a quasi-random scheme. The observer programme is combined with the collection of catch data which aims at an overall random coverage of $10 \%$. Therefore, the coverage in the fleet segments varies from year to year.

The fishing area of a freezertrawler trip is often not known until it leaves port and may change during the trip itself. In addition, the actual observer effort during transport towards -, from - and between fishing areas is not taken into account in this report for practical reasons. For example the assignment to metiers of sail- and search time is complicating - whereas an observer needs to be paid during the whole stay on board. More than half of the Dutch observer effort has been carried out on board foreign vessel and does not add to the coverage of the Dutch fleet, but to the German and French coverage. In fact the overall observer effort on board pelagic vessels operated by the Dutch would have easily exceeded $10 \%$ if all effort would have been dedicated to Dutch flagged vessel.

The recorded bycatch rate of cetaceans in the pelagic fishery is 0.00 (no cetaceans in 117 observed days), which is similar to rates found in 2005 - 2015. In the Dutch fishery, bycatches of dolphins occurred in the past mainly in the fishery for horse mackerel and mackerel west of Ireland in February and March (Couperus, 1997b). The relatively low bycatch rates in 2005 - 2015 compared to the rates in the nineties are probably related to a shift in effort from the horse mackerel towards the blue whiting fishery during these two months (Couperus, 2006).

Due to the high number of hauls without bycatches it is not possible to estimate the bycatch rate with any accuracy with the current observer effort. If extrapolated to the fleet the total bycatch mortality of cetaceans caused by Dutch pelagic freezertrawlers in the 2005-2015 seasons is in the order of magnitude of zero to several tens. However, data from the nineties suggest that the bycatch rate may vary, partly induced by changes in the quotas of pelagic target species (Couperus, 1997b).

In the set net monitoring programme no bycatch incidents were observed in 8 day trips. Earlier monitoring pilot studies resulted in zero bycatches in 34 day trips with gill nets for mullet and bass (Klinge, 2008); 1 harbour porpoise during 48 day trips with trammel- and gill nets (Couperus et al., 2009); 6 harbour porpoises in 24 REM-monitoring days and zero porpoises in 6 days of Remote Electronic Monitoring (REM) for sole and 4 for bass (Helmond and Couperus, 2011). Bycatch of harbour porpoises in the Dutch fishery is currently under investigation in an REM study over the period of 2012 to 2016, in which 10 vessels participate.

\section{References}

Couperus, A.S., 1995. By-catch of marine mammals and discards in pelagic trawl fisheries (BIOECO-Duch participation), Report to the European Commission 94/17. RIVO, IJmuiden, p. 15. 
Couperus, A.S., 1997a. By-catch of marine mammals and discards in pelagic fisheries (MAMDIS), Report to the European Commission 94/18. RIVO, IJmuiden, p. 21.

Couperus, A.S., 1997b. Interactions between Dutch midwater trawl and Atlantic white-sided dolphins (Lagenorhynchus acutus) southwest of Ireland. Journal of Northwest Atlantic Fishery Science 22, 209-218. Couperus, A.S., 2006. Monitoring of incidental catches of cetaceans by Dutch pelagic trawlers, July 2004 December 2005. Centrum voor Visserijonderzoek (CVO), IJmuiden, p. 24.

Couperus, A.S., Aarts, G., Giels, J.v., Haan, D.d., Keeken, O.v., 2009. Onderzoek naar bijvangst bruinvissen in de Nederlandse visserij, Rapport Wageningen IMARES/Aquaterra-Kuiperburger. Imares, IJmuiden, p. 90. Helmond, A.T.M.v., Couperus, A.S., 2011. Elektronische monitoring van kleinschalige staandwantvisserij. IMARES, IJmuiden, p. 25.

ICES, 2009. Report of the Study Group for Bycatch of Protected Species (SGBYC). ICES, Copenhagen, Denmark, p. 100.

Klinge, M., 2008. Ecologische inpasbaarheid staand want visserij kustwateren (exclusief Noordzeekustzone) Onderzoek naar bijvangst watervogels en zeezoogdieren. Witteveen \& Bos/Aquaterra-Kuiperburger, Rotterdam, p. 15. 


\section{TABLES}

Table 1. Pingers used in fleet segment set gill nets.

\begin{tabular}{|l|l|l|l|}
\hline Metier & \multicolumn{1}{|c|}{ Fishing area } & Pinger characteristics & $\begin{array}{c}\text { Other mitigation } \\
\text { measures }\end{array}$ \\
\hline- & - & - & - \\
\hline
\end{tabular}


Table 2. Fleet effort and observer effort in towed gear

\begin{tabular}{|c|c|c|c|c|c|c|c|c|c|c|c|c|c|c|c|c|}
\hline \multirow[b]{2}{*}{$\begin{array}{l}\text { Fishery segment } \\
\text { (ref in this report) }\end{array}$} & \multirow[b]{2}{*}{ Metier } & \multicolumn{7}{|c|}{ Total fishing effort } & \multicolumn{6}{|c|}{ Total observer effort achieved } & \multirow[b]{2}{*}{\begin{tabular}{|l|} 
Type of \\
monitoring*
\end{tabular}} & \multirow[b]{2}{*}{ Coverage } \\
\hline & & $\begin{array}{l}\text { Fishing } \\
\text { area }\end{array}$ & $\begin{array}{l}\text { No. of } \\
\text { vessels }\end{array}$ & $\begin{array}{l}\text { No. of } \\
\text { trips }\end{array}$ & $\begin{array}{l}\text { Days at } \\
\text { sea }\end{array}$ & $\begin{array}{l}\text { Months } \\
\text { of operation }\end{array}$ & $\begin{array}{l}\text { No. of } \\
\text { hauls }\end{array}$ & \begin{tabular}{|l|} 
Total \\
towing \\
time \\
\end{tabular} & $\begin{array}{l}\text { No. of } \\
\text { vessels }\end{array}$ & $\begin{array}{l}\text { No. of } \\
\text { trips }\end{array}$ & $\begin{array}{l}\text { Days at } \\
\text { sea }\end{array}$ & $\begin{array}{l}\text { Months } \\
\text { of operation }\end{array}$ & $\begin{array}{l}\text { No. of } \\
\text { hauls }\end{array}$ & \begin{tabular}{|l|} 
Total \\
towing \\
time $(\mathrm{min})$ \\
\end{tabular} & & \\
\hline NLD003 & OTM small pelagic fish & 27.6.a & 6 & 17 & 162 & $1,2,3 \& 12$ & unk & unk & 2 & 2 & 5 & $1,2,3 \& 12$ & 10 & 1640 & PMS & $3.1 \%$ \\
\hline NLD003 & OTM small pelagic fish & 27.7.b & 6 & 10 & 79 & $1,2,3 \& 12$ & unk & unk & 1 & 1 & 1 & $1,2,3 \& 12$ & 3 & 195 & PMS & $1.3 \%$ \\
\hline NLD003 & OTM small pelagic fish & 27.7.c & 6 & 11 & 39 & $1,2,3 \& 12$ & unk & unk & 2 & 2 & 4 & $1,2,3 \& 12$ & 7 & 945 & PMS & $10.3 \%$ \\
\hline NLD003 & OTM small pelagic fish & 27.7.d & 4 & 6 & 35 & $1,2,3 \& 12$ & unk & unk & 1 & 1 & 10 & $1,2,3 \& 12$ & 40 & 2995 & PMS & $28.6 \%$ \\
\hline NLD003 & OTM small pelagic fish & 27.7.e & 2 & 2 & 6 & $1,2,3 \& 12$ & unk & unk & 1 & 1 & 1 & $1,2,3 \& 12$ & 1 & 180 & PMS & $16.7 \%$ \\
\hline NLD003 & OTM small pelagic fish & 27.7.h & 1 & 1 & 1 & $1,2,3 \& 12$ & unk & unk & 0 & 0 & 0 & $1,2,3 \& 12$ & 0 & 0 & PMS & $0.0 \%$ \\
\hline NLD003 & OTM small pelagic fish & 27.7.j & 5 & 6 & 20 & $1,2,3 \& 12$ & unk & unk & 2 & 2 & 5 & $1,2,3 \& 12$ & 8 & 1760 & PMS & $25.0 \%$ \\
\hline NLD003 & OTM small pelagic fish & $27.7 . \mathrm{k}$ & 4 & 4 & 26 & $1,2,3 \& 12$ & unk & unk & 1 & 1 & 6 & $1,2,3 \& 12$ & 12 & 2790 & PMS & $23.1 \%$ \\
\hline NLD004 & OTM small pelagic fish & 27.2.a & 6 & 8 & 66 & $1-12$ & unk & unk & 0 & 0 & 0 & $1-12$ & 0 & 0 & PMS & $0.0 \%$ \\
\hline NLD004 & OTM small pelagic fish & 27.4.a & 7 & 29 & 275 & $1-12$ & unk & unk & 2 & 2 & 17 & $1-12$ & 42 & 7475 & PMS & $6.2 \%$ \\
\hline NLD004 & OTM small pelagic fish & 27.4.b & 7 & 20 & 81 & $1-12$ & unk & unk & 2 & 3 & 12 & $1-12$ & 19 & 2015 & PMS & $14.8 \%$ \\
\hline NLD004 & OTM small pelagic fish & 27.4.c & 3 & 6 & 12 & $1-12$ & unk & unk & 1 & 1 & 6 & $1-12$ & 19 & 2855 & PMS & $50.0 \%$ \\
\hline NLD004 & OTM small pelagic fish & 27.5.b & 4 & 5 & 27 & $1-12$ & unk & unk & 0 & 0 & 0 & $1-12$ & 0 & 0 & PMS & $0.0 \%$ \\
\hline NLD004 & OTM small pelagic fish & 27.6.a & 5 & 16 & 165 & $4-11$ & unk & unk & 3 & 3 & 39 & $4-11$ & 91 & 33316 & PMS & $23.6 \%$ \\
\hline NLD004 & OTM small pelagic fish & 27.7.b & 1 & 2 & 3 & $4-11$ & unk & unk & 0 & 0 & 0 & 4-11 & 0 & & PMS & $0.0 \%$ \\
\hline NLD004 & OTM small pelagic fish & 27.7.d & 5 & 10 & 70 & $4-11$ & unk & unk & 2 & 2 & 9 & 4-11 & 18 & 1535 & PMS & $12.9 \%$ \\
\hline NLD004 & OTM small pelagic fish & 27.7.e & 4 & 6 & 27 & $4-11$ & unk & unk & 1 & 1 & 2 & 4-11 & 3 & 275 & PMS & $7.4 \%$ \\
\hline NLD004 & OTM small pelagic fish & 27.7.g & 1 & 1 & 3 & $4-11$ & unk & unk & 0 & 0 & 0 & $4-11$ & 0 & 0 & PMS & $0.0 \%$ \\
\hline NLD004 & OTM small pelagic fish & 27.7.h & 1 & 1 & 1 & $4-11$ & unk & unk & 0 & 0 & 0 & $4-11$ & 0 & 0 & PMS & $0.0 \%$ \\
\hline NLD004 & OTM small pelagic fish & 27.7.j & 3 & 4 & 28 & $4-11$ & unk & unk & 0 & 0 & 0 & 4-11 & 0 & 0 & PMS & $0.0 \%$ \\
\hline NLD004 & OTM small pelagic fish & $27.8 . \mathrm{b}$ & 2 & 2 & 12 & $4-11$ & unk & unk & 0 & 0 & 0 & $4-11$ & 0 & & PMS & $0.0 \%$ \\
\hline
\end{tabular}

*PMS $=$ Pilot Monitoring Scheme 
Table 3. Fleet effort and observer effort in static gear (fleetsegment NLD007)

\begin{tabular}{|c|c|c|c|c|c|c|c|c|c|c|c|c|c|c|c|}
\hline \multirow[b]{2}{*}{ Metier } & \multirow[b]{2}{*}{$\begin{array}{c}\text { Fishing } \\
\text { area }\end{array}$} & \multicolumn{6}{|c|}{ Total fishing effort } & \multicolumn{6}{|c|}{ Total observer effort achieved } & \multirow[b]{2}{*}{$\begin{array}{c}\text { Type of } \\
\text { monitoring* }\end{array}$} & \multirow[b]{2}{*}{ Coverage } \\
\hline & & $\begin{array}{c}\text { No. of } \\
\text { vessels }\end{array}$ & $\begin{array}{l}\text { No.of } \\
\text { trips }\end{array}$ & $\begin{array}{c}\text { Days at } \\
\text { sea }\end{array}$ & $\begin{array}{c}\text { Months } \\
\text { of operation }\end{array}$ & \begin{tabular}{|c} 
Total \\
length of \\
nets
\end{tabular} & $\begin{array}{l}\text { Total } \\
\text { soak } \\
\text { time } \\
\end{array}$ & $\begin{array}{c}\text { No. of } \\
\text { vessels }\end{array}$ & $\begin{array}{c}\text { No.of } \\
\text { trips }\end{array}$ & $\begin{array}{c}\text { Days at } \\
\text { sea }\end{array}$ & \begin{tabular}{|c|}
$\begin{array}{c}\text { Months } \\
\text { of } \\
\text { operation }\end{array}$ \\
\end{tabular} & \begin{tabular}{|c|}
$\begin{array}{c}\text { Total } \\
\text { length of } \\
\text { nets }\end{array}$ \\
\end{tabular} & $\begin{array}{l}\text { Total } \\
\text { soak } \\
\text { time }\end{array}$ & & \\
\hline \begin{tabular}{|l|} 
Nets \\
\end{tabular} & 27.4.c & 7 & 60 & 64 & $1-12$ & unk & unk & 0 & 0 & 0 & $1-12$ & 0 & 0 & PMS & $0.0 \%$ \\
\hline GTR & 27.4.c & 9 & 96 & 96 & $10-12 \& 1-4$ & unk & unk & 2 & 2 & 2 & $10-12 \& 1-4$ & 11500 & 26 & PMS & $2.1 \%$ \\
\hline GNS & 27.4.b & 2 & 2 & 2 & $1-12$ & unk & unk & 0 & 0 & 0 & 0 & 0 & 0 & PMS & $0.0 \%$ \\
\hline GNS & 27.4.c & 87 & 1892 & 1968 & $1-12$ & unk & unk & 6 & 6 & 6 & $1-12$ & 72500 & 86 & PMS & $0.3 \%$ \\
\hline
\end{tabular}

\section{PMS = Pilot Monitoring Scheme}


Table 4. Bycatch rates. Incidental catch rates are expressed as in specimens/days.

\begin{tabular}{|c|c|c|c|c|c|c|c|c|c|c|c|}
\hline \multirow[b]{2}{*}{$\begin{array}{l}\text { Fishery } \\
\text { segment } \\
\text { (ref in this } \\
\text { report) }\end{array}$} & \multirow[b]{2}{*}{ Metier } & \multirow[b]{2}{*}{$\begin{array}{l}\text { Fishing } \\
\text { area }\end{array}$} & \multirow[b]{2}{*}{$\begin{array}{l}\text { Main target } \\
\text { species }\end{array}$} & \multirow[b]{2}{*}{$\begin{array}{l}\text { Incidental caught } \\
\text { species }\end{array}$} & \multirow[b]{2}{*}{$\begin{array}{l}\text { Number } \\
\text { of } \\
\text { incidents }\end{array}$} & \multicolumn{2}{|c|}{\begin{tabular}{|c|} 
Number of \\
specimens \\
incidentally caught \\
\end{tabular}} & \multicolumn{2}{|c|}{$\begin{array}{l}\text { Incidental } \\
\text { catch rates }\end{array}$} & \multirow[b]{2}{*}{$\begin{array}{l}\text { Total } \\
\text { incidental } \\
\text { catch } \\
\text { estimate } \\
\end{array}$} & \multirow[b]{2}{*}{$\mathrm{CV}$} \\
\hline & & & & & & $\begin{array}{l}\text { With } \\
\text { pingers }\end{array}$ & $\begin{array}{l}\text { Without } \\
\text { pingers }\end{array}$ & $\begin{array}{l}\text { With } \\
\text { pingers }\end{array}$ & $\begin{array}{l}\text { Without } \\
\text { pingers }\end{array}$ & & \\
\hline NLD003 & OTM small pelagic fish & 27.7.j & Horse mackerel & Thunnus thynnus & 1 & 0 & 1 & 0 & 0.2 & 4 & $200.0 \%$ \\
\hline NLD004 & OTM small pelagic fish & 27.7.d & Herring & Thunnus thynnus & 1 & 0 & 2 & 0 & 0.22 & 15.56 & $282.8 \%$ \\
\hline
\end{tabular}




\section{Signature}

The scientific quality of this report has been peer reviewed by a colleague scientist and Head of Centre for Fisheries Research.

CVO Report: CVO Report 18.008

Project number: 4311213026, 4311213027

Approved by:

Drs. H.J.M. van Overzee

Fisheries Scientist

Signature:

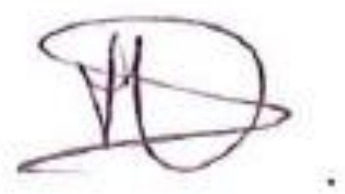

Date:

23 May 2018

Approved by:

Drs. S.W. Verver

Head of Centre for Fisheries Research

Signature:

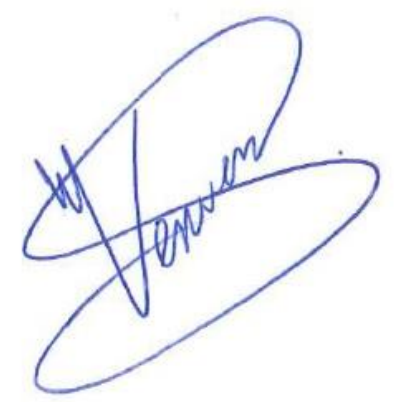

Date:

23 May 2018 